\title{
Geosciences
}

http://dx.doi.org/10.1590/0370-44672019730053

\author{
Ingrid de Souza Hoyer ${ }^{1,3}$ \\ https://orcid.org/0000-0001-7278-4375 \\ Valmir da Silva Souza ${ }^{1,4}$ \\ https://orcid.org/0000-0002-4957-5951 \\ Beatriz Pereira Debowski ${ }^{2,5}$ \\ https://orcid.org/0000-0002-4935-0832
}

'Universidade de Brasília - UnB, Instituto de Geociências, Brasília - Distrito Federal - Brasil.

${ }^{2}$ Universidade Estadual do Rio de Janeiro - UERJ, Faculdade de Geologia,

Rio de Janeiro - Rio de Janeiro - Brasil.

E-mails: ${ }^{3}$ ingridshoyer@gmail.com,

valmirsouzaunb@gmail.com,

5biadebowski@gmail.com

\section{Aquamarine from Massangana batholith, Rondônia State: mineral chemistry and fluid inclusion data}

\begin{abstract}
Beryl is usually found in granite-pegmatite systems. The addition of chromophore elements ( $\mathrm{V}, \mathrm{Cr}, \mathrm{Mn}, \mathrm{Fe}$ ) into the crystalline structure favors color changes in beryl and thus generates some of the world's expensive gems such as emerald, morganite, heliodor and aquamarine. The Massangana polyphasic batholith is a well-known cassiterite, wolframite and gems deposit in the Rondônia state. These metals and blue-gems (topaz and aquamarine) are located in feldspar-rich pegmatite granite bodies. The aquamarine crystals show color ranging from light- to medium-blue and display concentric growth zones. Electron-probe microanalyses revealed that the $\mathrm{Fe}$ is the main chromophore element, occupying the octahedral Al-site, while $\mathrm{Na}$ had an important role in the charge balance, inserted in the channel sites together with $\mathrm{H}_{2} \mathrm{O}$. The irregular supply of Fe and $\mathrm{Na}$ during the nucleation and growth of aquamarine was the main cause for the color change. A fluid inclusion study indicated that the aquamarine growth under an aqueous fluid system $\left(\mathrm{H}_{2} \mathrm{O}-\mathrm{NaCl}\right)$, with low salinity, low density and total homogenization temperature between $243^{\circ}-315^{\circ} \mathrm{C}$, is compatible with final temperatures in the pegmatite pocket zone.
\end{abstract}

Keywords: aquamarine, Massangana batholith, Rondônia, electron probe microanalysis (EPMA), mineral chemistry, microthermometry, fluid inclusion. 


\section{Introduction}

Gem-quality beryl is usually found in fractionated-granitic or granite-pegmatite systems. Beryl is a cyclosilicate with its simplest chemical formula $\mathrm{Be}_{3} \mathrm{Al}_{2}\left[\mathrm{Si}_{6} \mathrm{O}_{18}\right]$, organized in hexagonal rings of Si-tetrahedra structure parallel to (0001), crosslinked together both by Be-tetrahedra and Al-octahedra sites, forming a threedimensional framework. This crystalline structure has channels parallel to the caxis that may host alkali, $\mathrm{H}_{2} \mathrm{O}$ and $\mathrm{CO}_{2}$ molecules, favoring complex replacement by other cations, such as $\mathrm{Fe}^{2+}, \mathrm{Mn}^{2+}, \mathrm{Mg}^{2+}$ and $\mathrm{Li}^{+}$(Morosin, 1972; Aurisicchio et al., 1988; Sherriff et al., 1991; Artioli et al. 1993). The addition of the chromophore elements ( $\mathrm{Cr}, \mathrm{V}, \mathrm{Mn}, \mathrm{Fe})$ into

\section{Analytical methods}

All analytical procedures were performed at the laboratories at the Geoscience Institute of the Brasília University (IG-UnB). The studied samples were cut in tablets, with orientations parallel and perpendicular (basal section) to the c-axis. A thin section cut was made according to the basal plane of the sample for petrographic and electron probe microanalysis (EPMA). In addition, two double-polished thin sections (around $1 \mathrm{~mm}$ thickness), cut according to the basal plane and to the c-axis, were prepared for the study of fluid inclusions.

The chemical composition of aquamarine was obtained through

\section{Geological setting}

In the State of Rondônia occurs several Meso- to Neoproterozoic rapakivi granitic associations (Fig. 1a), emplaced during successive magmatic episodes between 1606 and $974 \mathrm{Ma}$, which make up the so-called Rondônia Tin Province (Kloosterman, 1968; Priem et al, 1966 and 1971; Leal et al., 1978; Isotta et al., 1978; Bettencourt et al., 1999; CPRM, 2007). However, the most significant metal concentrations ( $\mathrm{Sn}, \mathrm{W}, \mathrm{Nb}, \mathrm{Ta}$ ) and gems are associated to A-type highly-fractionated magmatic episodes, occurred between 1314 and $974 \mathrm{Ma}$, and are represented by São Lourenço-Caripunas (1314-1309 $\mathrm{Ma})$, Santa Clara (1082-1074 Ma) and Rondônia (995-974 Ma) intrusive suites (Bettencourt et al., 1999).

The Massangana batholith belongs the Al-structure favors color changes in beryl (Hawthorne and Huminicki, 2002), and thus generating some of the world's expensive gems such as emerald (Cr, V), morganite $(\mathrm{Mn})$, heliodor $(\mathrm{Fe}, \mathrm{Mn})$ and aquamarine $(\mathrm{Fe})$.

Brazil is a world's producer of aquamarine, whose main deposits are in Minas Gerais, Espírito Santo, Bahia, Paraíba, Rio Grande do Norte and Rondônia states (CPRM 2007, Barreto and Bittar 2010). In the Rondônia state, the Massangana batholith is a wellknown cassiterite and wolframite deposit, as well as producer of some gems (mainly topaz and beryl), which have been exploited applying an artisanal

electron probe microanalysis techniques (EPMA). A JEOL JXA-8230 microanalyzer with five coupled wavelength dispersive spectrometers (WDS) was used. The analytical conditions applied were: accelerating voltage of $20 \mathrm{kV}$, beam current of $40 \mathrm{nA}$, beam diameter of 1-2 $\mu \mathrm{m}$, and counting times of 15 and $10 \mathrm{~s}$ for peak and background positions, respectively. The data reduction was performed with the ZAF program and the following standards were used: microcline ( $\mathrm{K}, \mathrm{Al}, \mathrm{Si})$, albite $(\mathrm{Na})$, andradite $(\mathrm{Ca}, \mathrm{Fe})$, forsterite $(\mathrm{Mg})$, pyrophanite $(\mathrm{Mn}, \mathrm{Ti})$, chromite $(\mathrm{Cr})$ and pollucite (Cs). The results are reported as wt.\% oxide, and the number of ions

to the Rondônia Suite, and intrudes the Paleoproterozoic basement rocks of the Jamari Complex (Isotta et al., 1978; CPRM, 2007). It is a polyphasic granitic system with outstanding contrast through remote sensor and aerogeophysical products, marked by its ESE-WNW elliptical shape with ring-fault structure (Fig. 1b), and related to the successive magmatic phases (Kloosterman, 1967; Priem et al., 1971; Okida, 2001; CPRM, 2007). Four alkaline magmatic phases have been recognized (Fig. 1b): Massangana, Bom Jardim, São Domingos and Taboca, which are close in age (1096 - $993 \mathrm{Ma})$. The Massangana is the main and oldest phase composed of coarse rapakivi biotite-alkali-fedspar granite. The Bom Jardim and São Domingos phases are intrusive in the Massangana mining-type known as "garimpo". In this deposit, the metals and gems occurs within pegmatites and hydrothermal veins, but also occur in paleo-alluvial deposits. Despite these gems being known and traded over time, information about the gemological quality and mineralogical properties are still insufficient or inexistent (e.g. Souza et al., 2003; Debowski et al., 2013). Herein, we report on chemistry and fluid inclusion compositions of aquamarine, a blue variety of beryl from Massangana batholith, thus adding information about the mineralogical characteristics and the physical-chemical nature of the paleofluids trapped in this gem.

in mineral formula were calculated on the basis of $3 \mathrm{Be}$ and $18 \mathrm{O}$ atoms per formula unit $(\mathrm{apfu})$. For $\mathrm{H}_{2} \mathrm{O}$ content calculation, the equation proposed by Marshall et al., (2016) was applied.

The microthermometric measurements were carried out using a LINKAM THMS-600 heating-freezing system coupled to an Olympus BX-51 petrographic microscope with $10 x$ and 50x long distance objectives. The calibration-stage was performed using synthetic fluid inclusion standards, applying speed rates from $10^{\circ}$ to $5^{\circ} \mathrm{C} / \mathrm{min}$, with an estimated accuracy of $\pm 0.3^{\circ} \mathrm{C}$ for the freezing $\left(+25^{\circ}\right.$ to $\left.-100^{\circ} \mathrm{C}\right)$ and $\pm 5^{\circ} \mathrm{C}$ for the heating (up to $400^{\circ} \mathrm{C}$ ).

phase and composed of inequigranular biotite granites. Taboca is the youngest phase. It is composed of inequigranular syenite to quartz-syenite apophyses and intrudes the Bom Jardim phase (Priem et al., 1966; Romanini, 1982; Bettencourt et al., 1999; CPRM, 2007; Debowski, 2016).

Blue-gems, topaz and aquamarine, are located in feldspar-rich pegmatite granite bodies, related to the Bom Jardim and São Domingos phases. The pegmatites are often found within the contact zone between granite and Jamari Complex wall rocks, but may also occur in the granite. They are morphologically tabular to irregular shape, texturally simple or asymmetrically zoned, show medium to coarse grained, and their thickness and continuity are variable 
(Fig. 2a). Generally, these pegmatites present the following zonal sequence: a cortex of elongated biotite crystals radially arranged or in comb texture, marking the wall- or border-zone. The intermediate zone is dominant and composed of K-feldspar (partially altered to kaolin) quartz, mica (biotite) and $\mathrm{Na}-$ plagioclase (also argilized) inequigranular aggregates, whose crystals reach a size up to $1.5 \mathrm{~cm}$. In this zone, there also occur disseminated crystals of fluorite, topaz, cassiterite, wolframite, columbitetantalite and some sulfides. In the core- or pocket-zone, which is lenticular, the blue-gems (topaz and aquamarine) occur normally associated with quartz, cassiterite, wolframite columbite-tantalite and fluorite. In this place, the mineral assemblage may reach sizes above $5 \mathrm{~cm}$, normally embedded in kaolin.

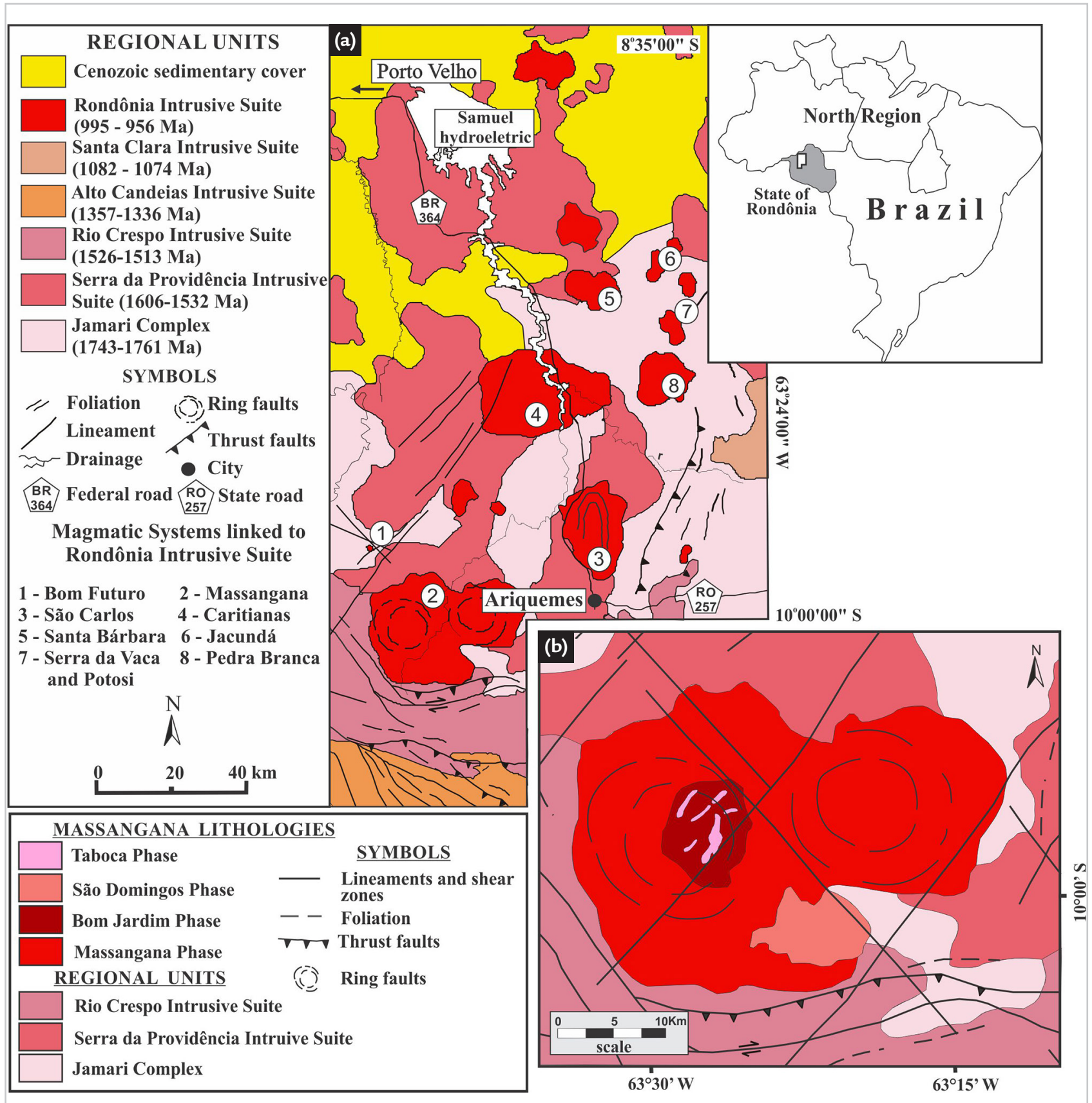

Figure 1 - a) Geological map of the central-northern portion of State of Rondônia, highlighting the granitic systems that make up the Rondônia Tin Province (modified from CPRM, 2007); b) Geological map of the Massagana polyphasic batholith (Debowski, 2016).

\section{Chemistry data}

The aquamarine is represented by euhedral to subhedral short to long crystals (Fig. 2b), slight to moderate fractured, with concentric growth zones and color ranging from light- to medium-blue. Frequently, the growth zones host some micro-inclusions (mainly feldspars and mica), but opaque and clay minerals also occur (Fig. 2c). Representative EPMA analyses for 30 different spots are summarized in Table 1. However, in Figure 2c, only part of these analyses are indicated (15 in total), which can be used to illustrate and verify the chemical variations inside the aquamarine crystal. The stoichiometric calculation results identified in Table 1 are applied due to the difficulty in obtaining EPMA accurate analytical results for $\mathrm{Be}$ and $\mathrm{H}_{2} \mathrm{O}$ (Groat et al., 2002). Therefore, the sum of the oxides goes to below $100 \mathrm{wt} . \%$ (commonly between 97 and $99 \mathrm{wt} . \%$ ). 
Table 1 - Intervals of EPMA analysis of the 30 different spots obtained in aquamarine crystal. The number of ions in mineral formula were calculated on the basis of $3 \mathrm{Be}$ and $18 \mathrm{O}$.

\begin{tabular}{|c|c|c|c|}
\hline Elements & Average & Minimum & Maximum \\
\hline $\mathrm{SiO}_{2}$ (wt.\%) & 66.99 & 65.87 & 67.89 \\
\hline $\mathrm{Al}_{2} \mathrm{O}_{3}$ & 16.96 & 16.64 & 17.38 \\
\hline $\mathrm{TiO}_{2}$ & 0.02 & 0.00 & 0.07 \\
\hline FeOtot. & 0.82 & 0.50 & 1.36 \\
\hline $\mathrm{Cr}_{2} \mathrm{O}_{3}$ & 0.02 & 0.00 & 0.13 \\
\hline $\mathrm{MgO}$ & 0.01 & 0.00 & 0.03 \\
\hline $\mathrm{MnO}$ & 0.02 & 0.00 & 0.09 \\
\hline $\mathrm{CaO}$ & 0.01 & 0.00 & 0.03 \\
\hline $\mathrm{Na}_{2} \mathrm{O}$ & 0.18 & 0.00 & 0.45 \\
\hline $\mathrm{K}_{2} \mathrm{O}$ & 0.01 & 0.00 & 0.04 \\
\hline $\mathrm{Cs}_{2} \mathrm{O}$ & 0.01 & 0.00 & 0.03 \\
\hline $\mathrm{BeO}^{*}$ & 13.72 & 13.55 & 13.90 \\
\hline $\mathrm{H}_{2} \mathrm{O}^{* *}$ & 1.07 & 0.00 & 1.75 \\
\hline Total & 98.74 & 97.51 & 99.94 \\
\hline Si (apfu) & 6.09 & 6.06 & 6.13 \\
\hline Al & 1.82 & 1.79 & 1.88 \\
\hline $\mathrm{Ti}$ & 0.00 & 0.00 & 0.01 \\
\hline $\mathrm{Fe}$ & 0.06 & 0.04 & 0.10 \\
\hline $\mathrm{Cr}$ & 0.00 & 0.00 & 0.01 \\
\hline $\mathrm{Mg}$ & 0.00 & 0.00 & 0.00 \\
\hline $\mathrm{Mn}$ & 0.00 & 0.00 & 0.01 \\
\hline $\mathrm{Ca}$ & 0.00 & 0.00 & 0.00 \\
\hline $\mathrm{Na}$ & 0.03 & 0.00 & 0.08 \\
\hline $\mathrm{K}$ & 0.00 & 0.00 & 0.01 \\
\hline Cs & 0.00 & 0.00 & 0.01 \\
\hline $\mathrm{Be}^{*}$ & 3.00 & 3.00 & 3.00 \\
\hline
\end{tabular}

The meaning of the symbols: ${ }^{*}=$ stoichiometric calculations, ${ }^{*}=$ stoichiometric calculated using the equation $\mathrm{H}_{2} \mathrm{O}=\left(0.5401 \times \ln \mathrm{Na}_{2} \mathrm{O}\right)+2.1867$ (Marshall et al., 2016), and ${ }^{* *}=$ ideal value for stoichiometric calculations.

The microanalyses were performed on a section perpendicular to the c-axis of the aquamarine crystal, following concentric growth zones (from edge to core) through profiles with spots approximately equidistant to each other (some of the analyses are shown in the Figures $2 \mathrm{c}$ and $2 \mathrm{~d}$ ). EPMA results revealed that the most important chromophore element for aquamarine is the $\mathrm{FeO}_{\text {total }}\left(\mathrm{Fe}^{3+}\right.$ and $\left.\mathrm{Fe}^{2+}\right)$, followed by some content trace of $\mathrm{TiO}_{2}, \mathrm{MnO}$ and $\mathrm{Cr}_{2} \mathrm{O}_{3}$ (Fig. 2d), which are close or below to the detection limit. Furthermore, it is important to note the

\section{Fluid inclusion data}

The petrographic study, at room temperature $\left( \pm 25^{\circ} \mathrm{C}\right)$, identified only aqueous primary and secondary/pseudo-secondary fluid inclusions. The primary fluid inclu- irregular and low $\mathrm{Na}$ content, as well as the very low $\mathrm{K}, \mathrm{Ca}$ and $\mathrm{Mg}$ contents (between $0-0.04 \mathrm{wt} . \%$ ). A tendency for positive correlation between $\mathrm{Fe}+\mathrm{Mg}$ and $\mathrm{Na}$ is observed (Fig. 2d and 2e), indicating the importance role of these compensating alkali ions. However, it is possible to note important variations on the $\mathrm{Fe}$ and $\mathrm{Na}$ contents: remarkable loss of $\mathrm{Na}$ at the edges, followed by progressive enrichment in the intermediate zone and ending with decreasing of $\mathrm{Fe}$ and $\mathrm{Na}$ in the central part of the aquamarine crystal. On the other hand, there is a tendency for negative cationic correlation between $\mathrm{Al}$ and the sum of $\mathrm{Fe}+(\mathrm{Mg}, \mathrm{Ti}, \mathrm{Cr}, \mathrm{Mn})$, which indicates that the major replacement process of these elements takes place within Aloctahedra site (Fig. 2f). The other trace elements with chromophore function (i.e., $\mathrm{Ti}, \mathrm{Cr}, \mathrm{Mn}$ ) have negligible participation (content below 0.10 wt.\%), but it is probable that some content of these trace elements also was accommodated to the Be-tetrahedra site (e.g., Aurisicchio et al., 1988; Hawthorne and Huminicki, 2002). sions occur isolated or in small groups, frequently followed the concentric growth zone, with size between 10-75 $\mu \mathrm{m}$, composed of mono- and biphasic morphol- ogy. On the other hand, the aquamarine crystals exhibit some microfractures or deformation features that contain fluid inclusions less than $10 \mu \mathrm{m}$ in size and 
showed monophasic morphology. These fluid inclusion types were classified as secondary or pseudo-secondary. This study addresses only the primary fluid inclusions, which display adequate sizes

for microthermometric observations.
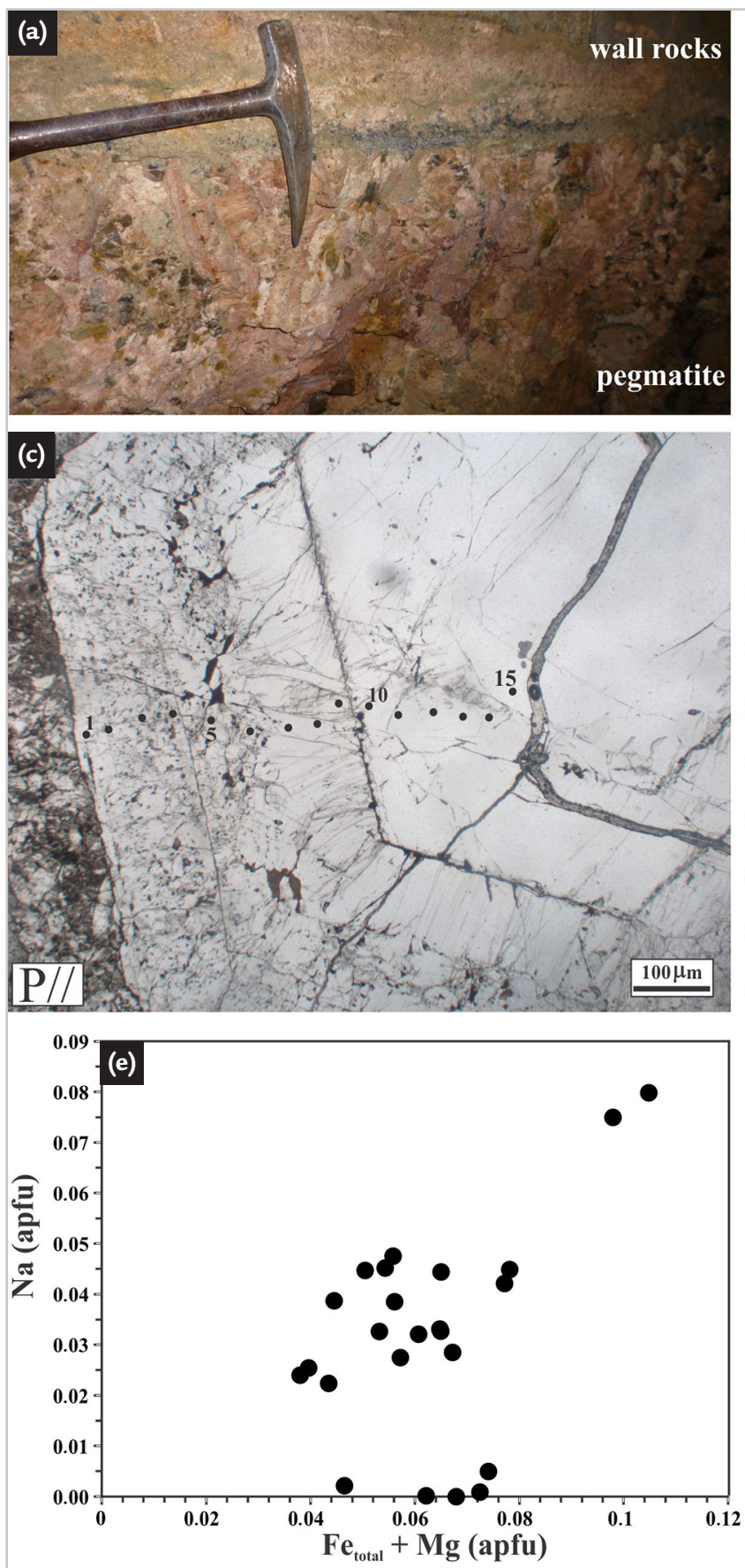
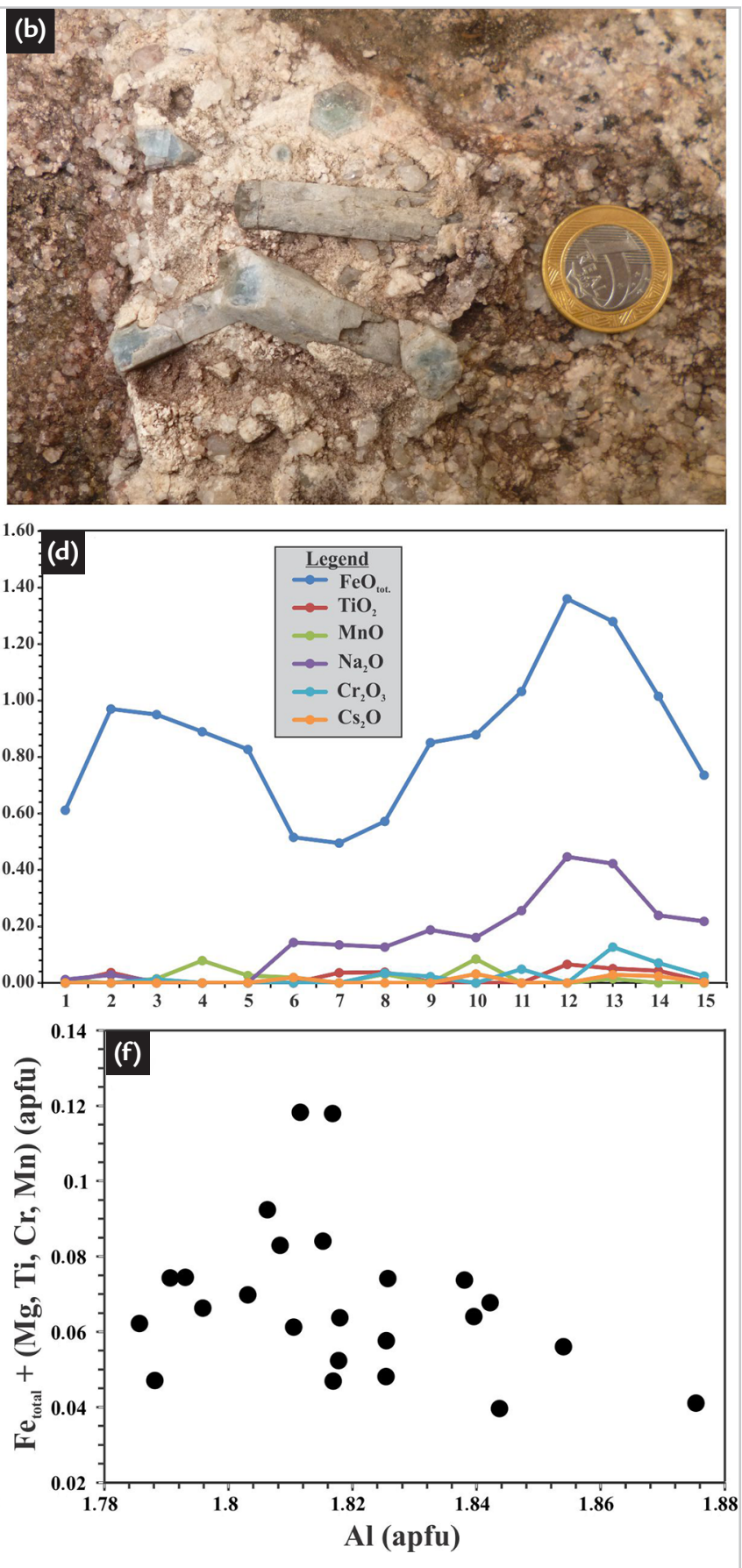

Figure 2 - a) Contact zone between tabular zoned pegmatite body and Jamari Complex wall-rocks; b) Euhedral short to long aquamarine crystals within granitic pegmatite, showing concentric growth zones and irregular coloration; c) photomicrography of a concentrically zoned aquamarine crystal. Note several micro-inclusions distributed mainly along the growth lines, as well as a set of electron-microprobe analyses along a crystal profile from edge to core (P// = parallel polars); $d$ ) Weight percent data for some selected oxides in aquamarine along a traverse. Note the tendency for positive correlation between $\mathrm{Fe}_{2} \mathrm{O}_{3 \text { total }}$ and $\mathrm{Na}_{2} \mathrm{O}$; e) Cationic correlation between Fetotal $+\mathrm{Mg} v s \mathrm{Na}$ (in apfu); and F) Cationic correlation between $\mathrm{Al}^{3+}$ vs sum of Fe $e_{\text {total }}+(\mathrm{Mg}, \mathrm{Ti}, \mathrm{Cr}, \mathrm{Mn}$ ) (in apfu).

\subsection{Petrography}

Two morphological types of primary aqueous fluid inclusions were identified and divided into: type 1 and type 2:

- Type 1 is most common and shows sizes between 40-75 $\mu \mathrm{m}$. It is composed of two immiscible phases: liquid-rich inclusions with a vapor bubble (liquid + vapor). The liquid phase shows colorless to slightly gray color and low birefringence, while the vapor phase exhibits dark gray to black color. The vapor/liquid volumetric ratios ( $\mathrm{F}$ factor) vary from 10 to $25 \%$. However, morphological variations lead to subdivision of type 1 into: $1 \mathrm{a}$ and type $1 \mathrm{~b}$. The type $1 \mathrm{a}$ shows sub-rounded to irregular shapes with $\mathrm{F}=10-20 \%$ (Fig. 3a). Occasionally, type 1a occurs hosting a solid phase, characterized by sub-rounded opaque micro-crystals with a size smaller than $5 \mu \mathrm{m}$ (Fig. $3 \mathrm{~b}$ ). 
On the other hand, the type $1 \mathrm{~b}$ presents elongated to cylindrical shape with $\mathrm{F}=20-25 \%$, usually parallel to the c- axis (Fig. 3c).

- Type 2 are monophasic, composed by a liquid phase. It shows a sub- rounded to elliptical shape, colorless to slightly gray color, low birefringence and size below $10 \mu \mathrm{m}$ (Fig. 3d).
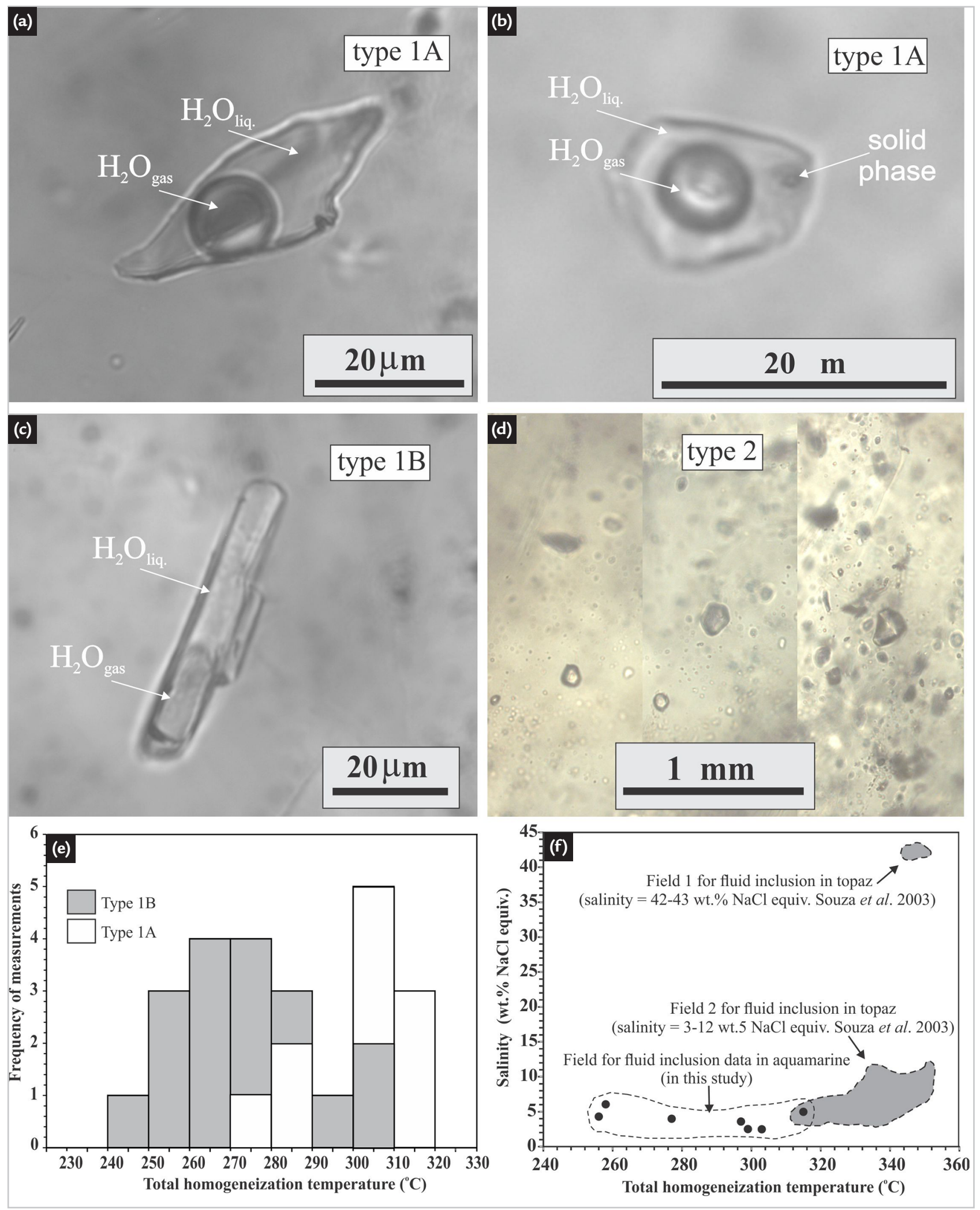

Figure 3 - Morphological features of main aqueous fluid inclusion types identified in the aquamarine crystals. a) and b) Morphological variation from type 1a aqueous fluid inclusions. Note in b, the type 1a sub-rounded shape and hosting an opaque micro-crystal (solid phase); c) Type 1B with cylindrical shape often found parallel to the c-axis; d) Type 3 fluid inclusion with sub-rounded to elliptical shape; e) Frequency histogram of total homogeneization temperatures (Thtot) of aqueous fluid inclusions at aquamarine (types 1a and 1b); and f) Total homogeneization temperatures vs salinity diagram applied to fluid inclusions data obtained in aquamarine. For a simple comparative analysis on the fluid inclusion data in gems from Massangana pegmatites available in literature.

We have also included in this diagram the fluid inclusion data obtained from topaz and reported by Souza et al. (2003). 


\subsection{Microthermometry}

Approximately 20 fluid inclusions were analyzed. During the tofreezing stage (below $-100^{\circ} \mathrm{C}$ ), it was observed that the vapor + liquid phases make up an aqueous fluid system $\left(\mathrm{H}_{2} \mathrm{O}_{\text {(vapor) }}+\mathrm{H}_{2} \mathrm{O}_{\text {(liquid) }}\right)$. In this context, only a few type 1 and type 2 fluid in- clusions showed appropriate size for observing the change phase for eutectic and ice final melt temperatures. The eutectic temperature was estimated between $-22.2^{\circ}$ and $-20.1^{\circ} \mathrm{C}$, while the ice final melt ( $\mathrm{Tm}$ ice) varied from $-2.2^{\circ}$ to $-1.1^{\circ} \mathrm{C}$ (Tab. 2). These data point for a $\mathrm{H}_{2} \mathrm{O}-\mathrm{NaCl}$ fluid system (e.g., Shepherd et al., 1985; Bodnar and Vityk, 1994). The salinity was estimated from Tm ice, which varies from 6 to 2.5 wt.\% $\mathrm{NaCl}$ equivalent, after applied the equation proposed by Bodnar (1993).

Table 2 - Microthermometric data summary on fluid inclusions obtained in aquamarine.

\begin{tabular}{|c|c|c|c|c|}
\hline \multirow{2}{*}{ Fluid inclusion types } & \multicolumn{4}{|c|}{ Microthermometric Intervals } \\
\hline & T eut. $\left({ }^{\circ} \mathrm{C}\right)$ & Tm. Ice $\left({ }^{\circ} \mathrm{C}\right)$ & Th total $\left({ }^{\circ} \mathrm{C}\right)$ & Salinity (\% wt. $\mathrm{NaCl}$ equiv.) \\
\hline Type 1A & \multirow{2}{*}{-22.2 to -20.1} & \multirow{3}{*}{-2.2 to -1.1} & $258.4-210.4$ & \multirow{3}{*}{2.5 to 6.0} \\
\hline Type 1B & & & $243.2-314.8$ & \\
\hline Type 2 & -21.4 to -20.4 & & - & \\
\hline
\end{tabular}

During the heating stage, the contraction of the vapor phase occurred until blending into the liquid phase $(\mathrm{L}+\mathrm{V} \rightarrow \mathrm{L})$ at the total homogeneization temperatures (Thtot.) between $243^{\circ}-315^{\circ} \mathrm{C}$ (Fig. 3e). On the other

\section{Discussion}

The color changes in beryl crystals are directly connected to the entrance in the crystalline structure of chromophore elements in the Al-octahedra site (Hawthorne and Huminicki, 2002). However, the geological setting has an important role in this chemical-replacement mechanism, which can be linked to fractional crystallization and metasomatism processes, for example (e.g., Simmons and Webber, 2008; Groat et al., 2008). The beryl-aquamarine variety linked to fractional crystallization of granitic-pegmatite phase is a result of nucleation and growth of crystals controlled by temperature decrease. In association, the entrance of Fe within the Al-bearing site is the main mechanism responsible for the blue color (Beal and Lentz, 2002; Viana et al., 2002, Groat et al., 2010).

Aquamarine from Massangana batholith has the Fe as the main cromophore element. The negative correlation between $\mathrm{Al}$ vs $\mathrm{Fe} \pm(\mathrm{Mg}, \mathrm{Ti}, \mathrm{Cr}, \mathrm{Mn})$ associated to positive correlation between $\mathrm{Fe}+\mathrm{Mg} v s \mathrm{Na}$, indicates that the major cationic replacement mechanism occurred within the octahedral Al-site. On the other hand, alkali ions (mainly $\mathrm{Na}$, followed by some $\mathrm{K}$ and $\mathrm{Ca}$ content) and $\mathrm{H}_{2} \mathrm{O}$ enter in the channel sites, positioning between the six-membered rings of Si tetrahedral of beryl structure, thus maintaining the hand, the final melt temperatures of solid phase from type 1B fluid inclusion were not measured, due to crepitation of some fluid inclusions at temperatures close to $400^{\circ} \mathrm{C}$. Probably this solid phase corresponds to minerals captured together with liquid-gas mixtures from hydrothermal solutions during formation of cavities. The fluid density was estimated around $0.95 \mathrm{~g} / \mathrm{cm}^{3}$, on base Thtot. vs salinity correlation (Shepherd et al., 1985). charge balance (Sampaio Filho et al., 1973; Aurisicchio et al., 1988; Sherriff et al., 1991; Groat et al., 2002).

The growth of aquamarine from Massangana batholith is marked by internal variations in color and chemical composition. The reasons for these variations are unclear. However, it is probable that some type of geochemical imbalance within the environment of growth leads mainly to lack of or irregular supply of $\mathrm{Fe}$ and $\mathrm{Na}$. This imbalance then favored color (from light blue to blue) and chemistry oscillation, respectively. According to Aurisicchio et al., (1988), zoning can occur because of chemical restrictions of the environment (bulk-rock chemistry and fluid-phase composition) or exchange reactions with other minerals, which can be influenced by changes in pressure, temperature and $\mathrm{pH}$ parameters. On the other hand, based on x-ray diffraction, Mössbauer, infrared and UV-visible spectra data, previous studies have shown that color change in beryl may be linked to charge imbalance created during the growth, relative to the proportion of $\mathrm{Fe}^{3+}$ in the octahedral sites and of $\mathrm{Fe}^{2+}$ in the channel sites (Viana et al., 2002; Groat et al., 2010).

$\mathrm{H}_{2} \mathrm{O}$-rich fluid phases are common in fractionated granitic melts emplaced at the upper crust (Bodnar, 1995; Roedder and Bodnar, 1997). Thermometry data indicate that the final temperatures in pegmatite pocket zones range from $390^{\circ}$ to $240^{\circ} \mathrm{C}$ (London, 1992; Johnson et al., 2002). Previous studies on the fluid inclusion in topaz, reported by Souza et al. (2003), associated with fluid inclusion data of aquamarine presented in this study, corroborated with the essentially aqueous $\left(\mathrm{H}_{2} \mathrm{O}-\mathrm{NaCl}\right)$ nature of the paleofluids in the Massangana pegmatites. However, important microthermometric differences between theses paleofluids can be observed. For example: paleofluids from topaz show different intervals of salinity (3-12 and $42-43$ wt.\% $\mathrm{NaCl}$ equiv.), density (0.65- 0.75 and above $1.2 \mathrm{~g} / \mathrm{cm}^{3}$ ) and Thtotal between $320^{\circ}-350^{\circ} \mathrm{C}$, indicating a fluid mixing process during evolution and cooling (Souza et al., 2003). On the other hand, paleofluids from the aquamarine show low salinity (2.5 - 6 wt.\% $\mathrm{NaCl}$ equiv.), density around $0.95 \mathrm{~g} / \mathrm{cm}^{-3}$ and Thtotal between $315^{\circ}-243^{\circ} \mathrm{C}$. These microthermometric data indicate that for topaz, this is linked to the fluids with variable salinity and higher temperatures, while for aquamarine, it is tied to fluids with lower salinity and temperature (Fig. 3f). Therefore, it is likely that the temperature decrease associated with the pressure drop and decrease in salinity 
in pegmatites pocket zone (e.g., London, 2008), accompanied by mixing with oth-

\section{Concluding remarks}

The data presented in this study led us to the following conclusions:

- The aquamarine is linked to the fractional crystallization in the graniticpegmatites phase. It is the result of nucleation and growth of crystals in the pocket zone, controlled by temperature decrease and marked by a concentric zoning and irregular color;

- The microthermometry data indi-

\section{Acknowledgements}

This research had financial support from the Brazilian National Council of Technological and Scientific Development (CNPq - REE Project n. 405839/2013-8). The authors are grateful to Geosci- ers aqueous fluids from the upper crust (e.g., Hedenquist 1995), were important mechanisms in the crystallization history of the Massangana pegmatites. cate that the aquamarine growth under an aqueous $\left(\mathrm{H}_{2} \mathrm{O}-\mathrm{NaCl}\right)$ fluid system with low salinity, low density e total homogenization temperature between $243^{\circ}-315^{\circ} \mathrm{C}$, is compatible to final temperatures in pegmatites pocket zone.

- Fe is the main chromophore element, which replaces the octahedral Alsite. This can be demonstrated by a negative correlation between $\mathrm{Al}$ and Fetotal.
On the other hand, the alkalis (mainly $\mathrm{Na}$, occupy the channel sites together with $\mathrm{H}_{2} \mathrm{O}$, and have an important role in the charge balance;

- The internal variations in color and chemical composition in aquamarine are mainly attributed to some type of geochemical imbalance that led to the lack or irregular supply of $\mathrm{Fe}$ and $\mathrm{Na}$ within the environment of growth. ence Institute of the Brasília University (IG-UnB) for laboratory support, especially to the Prof. Dr. N. F. Botelho (EPMA laboratory coordinator). A special thanks to Massangana Miners Asso- ciation and Brazilian Geological Survey (CPRM/Rondônia office) for fieldwork support. This research is linked to the Precambrian Metallogeny Research Group from the IG-UnB/CNPq.

\section{References}

ARTIOLI, G.; RINALDI, R.; STAHL, K.; ZANAZZI, P. F. Structure refinements of beryl by single-crystal neutron and X-ray diffraction. American Mineralogists, v. 78, p. 762-768, 1993.

AURISICCHIO, C.; FIORAVANTI, O.; GRUBESSI, O.; ZANAZZI, P. F. Reappraisal of the crystal chemistry of beryl. American Mineralogists, v. 73, n. 7-8, p. 826-837, 1988.

BARRETO, S. B.; BITTAR, S. M. B. The gemstone deposits of Brazil: occurrences, production and economic impact. Boletín de la Sociedad Geológica Mexicana, v. 62, n. 1, p.123-140, 2010.

BEAL, K-L.; LENTZ, D. R. Aquamarine beryl from Zealand Station, Canada: a mineralogical and stable isotope study. Journal of Geosciences, v. 55, n. 1, p. 57-67, 2002. DOI: http://dx.doi.org/10.3190/jgeosci.059.

BETTENCOURT, J. S.; TOSDAL, R. M.; LEITE Jr., W. B.; PAYOLLA, B. L. Mesoproterozoic rapakivi granites of the Rondônia Tin Province, southwestern border of the Amazonian craton, Brazil - I. Reconnaissance U-Pb geochronology and regional implications. Precambrian Research, v. 95, n. 1-2, p. 41-67, 1999.

BODNAR, R. J. Revised equation and table determining the freezing point depression of $\mathrm{H} 2 \mathrm{O}-\mathrm{NaCl}$ solutions. Geochimica et Cosmochimica Acta, v. 57, p. 683-684, 1993. DOI: 10.1016/0016-7037(93)90378-A.

BODNAR, R. J.; VITYK, M. O. Interpretation of microthermometric data for $\mathrm{H}_{2} \mathrm{O}-\mathrm{NaCl}$ fluid inclusions. In: $\mathrm{DE}$ VIVO, B.; FREZZOTTI, M. L. (ed.). Fluid inclusions in minerals: methods and applications: short course of the working group (IMA) “Inclusions in Minerals”, Pontignano-Siena, 1994. Blacksburg, VA: Virginia Tech, 1994. p. $117-130$.

BODNAR, R. J. Fluid inclusion evidence for a magmatic source for metals in porphyry copper deposits. In: THOMPSON, J. F. H. (ed.). Magmas, fluids and ore deposits. Canada: Mineralogical Association of Canada, 1995. p. 39-152. (Short course series, v.23).

DEBOWSKI, B. P.; REIS, M. J.; VIANA, R. R. Caracterização química e mineralógica de topázios do Complexo Massangana, região central de Rondônia. In: SIMPÓSIO DE GEOLOGIA DO CENTRO-OESTE, 13., 2013, Cuiabá. Anais [...]. Cuiabá: SGCO, 2013.

DEBOWSKI, B. P. Caracterização petrológica de Maciços das Suites Intrusivas Rondônia e Serra da Providência com base em dados litogeoquímicos e petrográficos e isotópicos (U-Pb e Lu-Hf) em zircão. 2016. 117 f. Dissertação (Mestrado em Geociências) - Faculdade de Geologia, Universidade do Estado do Rio de Janeiro, Rio de Janeiro, 2016.

GROAT, L. A.; MARSHALL, D. D.; GIULIANI, G.; MURPHY, D. C.; PIERCEY, S. J.; JAMBOR, J. L.; MORTENSEN, J. K.; ERCIT, T. S.; GAULT, R. A.; MATTEY, D. P.; SCHWARZ, D.; MALUSKI, H; WISE, M. A.; WENGZYNOWSKI, W.; EATON, D. W. Mineralogical and geochemical study of the Regal Ridge Emerald Showing, Southeastern Ukon. The Canadian Mineralogist, v. 40, n. 5, p. 1313-1338, 2002.

GROAT, L. A.; GIULIANI, G.; MARSHALL, D. D.; TURNER, D. Emerald deposits and occurrences: a review. Ore Geology Reviews, v. 34, n. 1-2, p. 87-112, 2008. DOI: https://doi.org/10.1016/j.oregeorev.2007.09.003.

GROAT, L. A.; ROSSMAN, G. R.; DYAR, M. D.; TURNER, D.; PICCOLI, P. M. B.; SCHULTZ, A. J.; OTTOLINI, L. Crystal chemistry of dark blue aquamarine from the true blue showing, Ukon Territory, 
Canada. The Canadian Mineralogist, v. 48, n. 3, p. 597-613, 2010. DOI:10.3749/canmin.48.3.597.

HAWTHORNE, F. C.; HUMINICKI, D. M. C. The crystal chemistry of beryllium. In: GREW, E. S. (ed.). Beryllium: mineralogy, petrology and geochemistry. [S. l.]: [s.n.], 2002. p. 333-403. (Reviews in Mineralogy \& Geochemistry, v. 50).

HEDENQUIST, J. W. The ascent of magmatic fluid: discharge versus mineralization. In: THOMPSON, J. F. H. (ed.). Magmas, fluids and ore deposits. Canada: Mineralogical Association of Canada, 1995. p. 263-289. (Short course series, v.23).

ISOTTA, C. A. L.; CARNEIRO, J. M.; KATO, H. T.; BARROS, R. J. L. Projeto Província Estanífera de Rondônia: relatório final. Porto Velho: MME/DNPM/CPRM, 1978. 407p.

JOHNSON, S.E., SCHIMIDT, K.L., TATE, M.C. Ring complexes in the Peninsular Tanges Batholith, Mexico and the USA: magma plumbing systems in the middle and upper crust. Lithos, v.61, p.187-208, 2002.

KLOOSTERMAN, J. B. Ring-structures in the Oriente e Massangana granite complexes, Rondônia, Brasil. Revista de Engenharia, Mineração e Metalurgia, v. 45, n. 266, p. 73-77, 1967.

KLOOSTERMAN, J. B. Uma província do tipo nigeriano no sul da Amazônia (Parte 1). Revista de Engenharia, Mineração e Metalurgia, v. 47, n. 278, p. 59-64, 1968.

LEAL, J. W. L.; SILVA, G. H.; SANTOS, D. B.; TEIXEIRA, W.; LIMA, M. I. C.; FERNANDES, C. A. C.; PINTO, A. C. Geologia. In: PROJETO RADAMBRASIL. Folha SC.20 Porto Velho: geologia, geomorfologia, pedologia, vegetação, uso potencial da terra. Rio de Janeiro: DNPM, 1978. p. 19-184. (Levantamento de Recursos Naturais, v. 16).

LONDON, D. The application of experimental petrology to the genesis and crystallization of granitic pegmatites. The Canadian Mineralogist, v. 30, n. 3, p. 499-540, 1992.

LONDON, D. Pegmatites. [S. l.]: The Mineralogical Association, 2008. 347p. (The Canadian Mineralogist, Special Publication n.10).

MARSHALL, D.; DOWNES, P. J.; ELLIS, S.; GREENE, R.; LOUGHREY, L.; JONES, P. Pressure-temperature-fluid constraints for the Poona emerald deposits, Western Australia: fluid inclusion and stable isotope studies. Minerals, v. 6, n. 4, p. 130, 2016.

MOROSIN, B. Structure and thermal expansion of beryl. Acta Crystallographica, v. 28, p. 1899-1903, 1972. DOI: https://doi.org/10.1107/S0567740872005199.

OKIDA, R. Aplicação do sensoriamento remoto e aerogamaespectrometria ao estudo do controle estrutural dos granitos estaniferos de Rondônia. 2001. 217 f. Tese (Doutorado em Geociências) - Instituto de Geociências, Universidade de São Paulo, São Paulo, 2001.

PRIEM, H. N. A.; BOELRIJK, N. A. I. M.; HEBEDA, E. H.; VERSCHURE, R. H.; BOM, E. H. Isotopic age of tin granites in Rondônia, N.W. Brazil. Geologie en Mijnbouw, v. 45, p. 191-192, 1966.

PRIEM, H. N. A.; BOELRIJK, N. A. I. M.; HEBEDA, E. H.; VERDURMEN, E. A. TH.; VERSCHURE, R. H.; BOM, E. H. Granitic complexes and associated tin mineralizations of "Grenville" age in Rondônia, western Brazil. Geological Society of America Bulletin, v. 82, n. 4, p. 1095-1102, 1971.

ROEDDER, E.; BODNAR, R. J. Fluid inclusions studies of hydrothermal ore deposits. In: BARNES H. L. (ed.). Geochemistry of Hydrothermal Ore Deposits. $3^{\mathrm{a}}$ ed. New York: John Wiley CO., 1997. p.657-697.

ROMANINI, S. J. Geologia e geoquímica do complexo granitóide de Massangana e sua relação com as mineralizações de estanho. 1982. 85 f. Dissertação (Mestrado em Geologia) - Instituto de Geociências, Universidade Federal da Bahia, Salvador, 1982.

SAMPAIO FILHO, H. A.; SIGHNOLFI, G. P.; GALLI, E. Contribution to the crystal chemistry of beryl. Contribution to Mineralogy and Petrology, v. 38, p. 279-290, 1973.

SERVIÇO GEOLÓGICO DO BRASIL. Geologia e recursos minerais do estado de Rondônia: Sistema de Informações Geográficas - SIG: texto explicativo do mapa geológico e de recursos minerais do estado de Rondônia - Escala 1:1.000.000. Porto Velho: CPRM, 2007. 153p. 1 CD-ROM.

SHEPHERD, T. J.; RANKIN, A. H.; ALDERTON, D. H. M. A practical guide to fluid inclusion studies. New York: Chapman and Hall, 1985. 239 p.

SHERRIFF, B. L.; GRUNDY, H. D.; HARTMAN, J. S.; HAWTHORNE, F. C.; CERNY, P. The incorporation of alkalis in beryl: multi-nuclear MAS NMR and crystal-structure study. Canadian Minerologist, v. 29, p. 27l-285, 1991.

SIMMONS, W. B.; WEBBER, K. Pegmatite genesis: State of the art. European Journal of Mineralogy, v. 20, n. 4, p. 421438. 2008. DOI: 10.1127/0935-1221/2008/0020-1833.

SOUZA, V. S.; PONTES, R. M.; MOURA, M. A. Inclusões fluidas em topázio do Complexo Granítico Estanífero de Massangana (RO). REM - Revista Escola de Minas, v. 56, n. 4, p. 231-236, 2003.

VIANA, R. R.; JORDT-EVANGELISTA, H.; COSTA, G. M.; STERN, W. B. Characterization of beryl (aquamarine variety) from pegmatites of Minas Gerais, Brazil. Physics and Chemistry of Minerals, v. 29, n. 10, p. 668-679, 2002. DOI: 10.1007/s00269-002-0278-y.

Received: 22 April 2019 - Accepted: 17 February 2020. 